\title{
Employee Empowerment, Learning Culture and Technology in a Research-based Organization
}

\author{
Noreen Natasha Azmee, Norliya Ahmad Kassim \\ Faculty of Information Management \\ Universiti Teknologi MARA (UiTM), \\ Malaysia
}

\begin{abstract}
An organization that wishes to stay relevant and achieve competitive advantage must apply the practices of learning organization. A learning organization is a place where people in the organization are learning very powerfully so that the skills and knowledge they own can boost their organizational performance at the maximum. This paper presents the results of a study that examines the perceptions on the practices of learning organization in terms of employee empowerment, learning culture, and technology in learning activities among staff in one research-based organization in the Klang Valley, Malaysia. In this pilot study, questionnaires were distributed to the selected staff of the organization of which all had responded. The result shows positive perceptions with regard to employee empowerment, learning culture, and use of technology in learning activities among staff in the organization. The results are useful to organizations that aspire to become a learning organization.
\end{abstract}

\section{Introduction}

In this knowledge era, organization that becomes learning organization is a one step ahead among others thus lead to achieve competitive advantage. Senge, the guru of Learning Organization, defined learning organization as "organization where people continually expand their capacity to create the results they truly desire, where new and expansive patterns of thinking are nurtured, where collective aspiration is set free, and where people are continually learning to see the whole together" [1]. [2] described a learning organization as an organization that facilitates learning of all its members and continually transforms itself. Besides that, [3] affirmed learning organization as organization that has the capability to look forward and adapt more readily to environmental impacts thus making greater organizational use of employee at every levels of the organization. A learning organization is where people at all levels whether individual and as a group continues to increase their ability to transform itself to meet demands for fundamental change in the aspects of vision, management and leadership, organization structure, culture, systems and process
[4], [5]. In today's economy, the growth of learning organization concept is raised and defined in different ways due to the need for organizations to persist the success and competitiveness of organization [6].

According to [1] in his book "The Fifth Discipline", there are five components of learning organization namely, systems thinking, personal mastery, shared vision, mental model, and team learning. [7] identified the elements in creation of learning organization such as: organizational learning strategy, participate in policy making, technology, people empowerment, rewards and incentives, decision making based on availability of data, and encouragement and support for staffs to take part in learning activities. Systematic problem solving, experimentation, learning, and transferring knowledge are the activities suggested by [8] to become a learning organization. [9] recognized organizational learning as one of the characteristics in creating learning organization that emphasized application of knowledge to improve organizational performances. In addition, [10], [11] emphasized the attributes to become a learning organization such as continuous learning, inquiry and dialogue, team learning, empowerment, technology, system connection, and leadership. For an organization to be a learning organization, [12] stressed that organization must engage with knowledge and skill. [13] proposed four subsystems (organization, people, knowledge, and technology) for an organization to build a learning organization.

Table 1: Dimensions of Learning Organization

\begin{tabular}{|c|c|}
\hline Dimensions & Source \\
\hline Systems thinking & {$[1]$} \\
\hline Personal mastery & {$[1]$} \\
\hline Shared vision & {$[1],[4],[5]$} \\
\hline Mental model & {$[1]$} \\
\hline Team learning & {$[1],[8],[10],[11]$} \\
\hline Organizational learning strategy & {$[7]$} \\
\hline Participate in policy making & {$[7],[15]$} \\
\hline Technology & {$[7]$} \\
\hline People empowerment & {$[7],[8]$} \\
\hline Rewards and incentives & {$[7],[13]$} \\
\hline Decision making & {$[13]$} \\
\hline People &
\end{tabular}




\begin{tabular}{|c|c|}
\hline Knowledge & {$[8],[12],[13]$} \\
\hline Learning & {$[8],[9],[10],[11]$} \\
\hline
\end{tabular}

Organizations that are learning organizations encourage learning for all members. Learning is the key to success in today's organization. Hence, the organizations must apply the practices of learning organization such as in terms of employee empowerment, learning culture, and technology thus enable the organization to be nurtured as a learning organization so as to become competitive in the challenging environment. Thus, this study aims to find out whether learning organization is being practiced in a research-based organization. Specifically, the objectives of this study are as follows:

- To examine whether the staff of the organization are aware of their organization being a learning organization

- To identify the facilities that support learning activities

- To determine staff's perception whether their organization is practicing the learning organization in terms of employee empowerment, learning culture and technology in their organization

\section{Literature Review}

\subsection{Employee Empowerment}

According to [7], [15] empowerment is one attributes of learning organization. Empowerment is "the process of gaining freedom and power to do what you want or to control what happens to you" [14]. One way for employee to gain empowerment is to upgrade their knowledge $[13,15]$ such as enroll courses or training modules that can improve their daily tasks. [16] described that empowerment allows employee to participate in decision making and power sharing. In a previous study by [17], they identified the role of empowerment in a learning organization that employee at each levels are involved and can have empowerment on decision making but it is not promised that this attribute can increase in learning activities. In addition, learning culture in an organization empowers employee to accomplish dramatically improved results compared to traditional organizations [18]. [19] stated that leader's action shape the structure, decision-making process and teamwork in an organization. In learning organization, good leaders encourage teamwork, empowerment and risk-taking [20]. In addition, [21] highlighted that leaders in learning organizations must empower their staffs to participate in the organization's goal. According to [22], empowerment is important in a learning environment. Employee in the lower ranks of an organization will be encouraged and motivated to form learning culture. In addition, [23] discovered that participation of employee in learning activities depends on roles, culture, styles of leadership, individual willingness, and organization structure.

\subsection{Learning Culture}

Learning is not limited to an individual but it comprises the entire organization which leads to the term 'learning organization'. Learning culture is important in organization and learning can be cultivated [12]. They also mentioned that the commitment of learning must have full support from the top management, where people at all levels were encouraged to learn, develop and point out their ideas. Moreover, [24] asserted that to have a proactive learning culture, an organization obliges expenditure of time and resources. They also identified some key contributors to adopt learning culture in organization such as: performance, aging workforce, distributed workforce, best solutions, and development of organization. [25] presented the benefits of learning culture in organization that comprises of filling the skills gap, better employee productivity, and create career development. A study by [26] confirmed that employees that have accessed to learning opportunities performed effectively in their organization.

\subsection{Technology}

The use of technology has brought paradigm shift in learning organization. Technology is the most powerful factor to formulate and carry out the business strategies in organization [27]. A study undertaken by [28] revealed that technology facilitates the way of learning and gaining knowledge among the staff. [13] stressed the power of technology in learning organization such as:

- To strengthen organizational identity,

- To build and sustain the communities of learning

- To keep employee, clients and others informed and aware of company development

- To encourage innovation and creativity

- To share and learn the best practices

- To enable staff to identify internal sources of expertise.

The study conducted by [27] also determined the relationship between technology practices, organizational learning, firm innovation and firm performance in the competitive environment resulting these variables as key components to improve innovation that provides high organization performance. 


\section{Research Methodology}

In this pilot study, the actual respondents were selected randomly among all levels of staff in three departments in one research-based organization in the Klang Valley, Malaysia. A total of twenty staff from all levels in the organization were chosen as the sample of the study. This study employed the survey method and using questionnaire as the instrument. The questionnaire was designed to examine staff's perceptions on the learning organization's aspects on employee empowerment, learning culture, and technology which are being practiced in the organization. The items in the questionnaire was designed on a 1 (strongly disagree) to 5 (strongly agree) Likert scale. Questionnaires were distributed to the twenty respondents and all returned the questionnaires. After the questionnaires were returned by the respondents, data analysis process was conducted. Descriptive statistics including frequency and percentage were performed.

\section{Findings}

\subsection{Demographic Profile}

The respondents were made up of a larger proportion $(50 \%)$ that came from the middle management, $25 \%$ from the senior management while the remaining $15 \%$ and $10 \%$ came from the lower management and non-management technical/ professional respectively. On the educational experience of the respondents, almost half (45\%) had a bachelor degree, a quarter $(25 \%)$ obtained a diploma and $20 \%$ had SPM/STPM. A small proportion $(5 \%)$ of the respondents had a master's degree.

\subsection{Awareness in Learning Organization}

This section reveals the respondents awareness regarding their organization being a learning organization. As shown in Table 2, majority (85\%) of the respondents were aware that their organization is a learning organization while only $15 \%$ respondents were not aware of it. The largest proportion $(85 \%)$ of the respondents knew that some kinds of learning activities had taken place in their organization while the remaining $15 \%$ were not aware about it. All (100\%) of respondents agreed that learning activities is important in their organization. Majority (85\%) of the respondents agreed that their organization is concerned about learning compared to only $15 \%$ who did not agree to it.
Table 2: Awareness in Learning Organization

\begin{tabular}{|l|c|c|}
\hline \multicolumn{1}{|c|}{ Statements } & Yes & No \\
\hline $\begin{array}{l}\text { I am aware that my organization is a } \\
\text { learning organization }\end{array}$ & $\begin{array}{c}17 \\
(85 \%)\end{array}$ & $\begin{array}{c}3 \\
(15 \%)\end{array}$ \\
\hline $\begin{array}{l}\text { I know that learning activities have } \\
\text { taken place in my organization }\end{array}$ & $\begin{array}{c}17 \\
(85 \%)\end{array}$ & $\begin{array}{c}3 \\
(15 \%)\end{array}$ \\
\hline $\begin{array}{l}\text { I feel learning activities is important } \\
\text { in my organization }\end{array}$ & $\begin{array}{c}20 \\
(100 \%)\end{array}$ & 0 \\
\hline $\begin{array}{l}\text { My organization is concerned about } \\
\text { learning activities }\end{array}$ & 17 & 3 \\
$(85 \%)$ & $(15 \%)$ \\
\hline
\end{tabular}

Note: $n=20$

\subsection{Facilities to Support Learning Activities}

Respondents were also asked about their usage of facilities that were provided in their organization to support learning activities. Respondents were allowed to choose more than one answer. The result as depicted in Table 3 shows that all (100\%) respondents used meeting room as a facility to support learning activities, $85 \%$ used KM portal, $70 \%$ used newsletter, $50 \%$ did discussion while the remaining $30 \%$ used bulletin to support their learning activities in the organization.

Table 3: Facilities to Support Learning Activities

\begin{tabular}{|c|c|}
\hline $\begin{array}{c}\text { Facilities provided in my organization } \\
\text { to support learning activities }\end{array}$ & Frequency \\
\hline Meeting room & $20(100 \%)$ \\
\hline KM portal & $17(85 \%)$ \\
\hline Newsletter & $14(70 \%)$ \\
\hline Discussion & $10(50 \%)$ \\
\hline Bulletin & $6(30 \%)$ \\
\hline
\end{tabular}

\subsection{Perceptions on Employee Empowerment in Organization}

Respondents were asked to indicate their perceptions regarding employee empowerment using a Likert Scale of 1-Strongly Disagree, 2-Disagree, 3Not Sure, 4-Agree, and 5-Strongly Agree. Table 4 illustrates the result on the perceptions of respondents regarding the practice of employee empowerment in the organization. It can be seen that $30 \%$ and $40 \%$ of the respondents strongly agreed and agreed respectively that their leader empowered staff to participate in organizational goal although $30 \%$ were not sure about it. Their leader also allowed staff to participate in decision-making process with $35 \%$ agreed and 20\% strongly agreed, respectively. However, a bigger proportion (45\%) were not sure about it. Respondents were also positive about their leader in encouraging delegation of works to lower staff where $45 \%$ agreed and another $40 \%$ strongly agreed with the statement. Only a small proportion $(15 \%)$ was unsure that their leader encouraged delegation of works to the lower staff. The result also found that $45 \%$ of the respondents agreed that 
their organization expected leadership practices to staff at all levels, 35\% respondents were not sure while $20 \%$ strongly agreed with the statement.

Table 4: Employee Empowerment in Organization

\begin{tabular}{|c|c|c|c|c|c|}
\hline Statements & SD & D & $\mathbf{N}$ & $\mathbf{A}$ & SA \\
\hline $\begin{array}{l}\text { 1. My leader } \\
\text { empowers } \\
\text { staff to } \\
\text { participate in } \\
\text { organization } \\
\text { goal }\end{array}$ & 0 & 0 & $\begin{array}{c}6 \\
(30 \%)\end{array}$ & $\begin{array}{c}8 \\
(40 \%)\end{array}$ & $\begin{array}{c}6 \\
(30 \%)\end{array}$ \\
\hline $\begin{array}{l}\text { 2. My leader } \\
\text { allows staff to } \\
\text { participate in } \\
\text { decision- } \\
\text { making }\end{array}$ & 0 & 0 & $\begin{array}{c}9 \\
(45 \%)\end{array}$ & $\begin{array}{c}7 \\
(35 \%)\end{array}$ & $\begin{array}{c}4 \\
(20 \%)\end{array}$ \\
\hline $\begin{array}{l}\text { 3. My leader } \\
\text { encourages } \\
\text { delegation of } \\
\text { work to lower } \\
\text { staff }\end{array}$ & 0 & 0 & $\begin{array}{c}3 \\
(15 \%)\end{array}$ & $\begin{array}{c}9 \\
(45 \%)\end{array}$ & $\begin{array}{c}8 \\
(40 \%)\end{array}$ \\
\hline $\begin{array}{ll}\text { 4. } & \text { My } \\
\text { organization } \\
\text { expected } \\
\text { leadership } \\
\text { practices to } \\
\text { staff at all } \\
\text { levels }\end{array}$ & 0 & 0 & $\begin{array}{c}7 \\
(35 \%)\end{array}$ & $\begin{array}{c}9 \\
(45 \%)\end{array}$ & $\begin{array}{c}4 \\
(20 \%)\end{array}$ \\
\hline
\end{tabular}

Note: $\mathrm{SA}=$ Strongly Disagree; $\mathrm{D}=$ Disagree; $\mathrm{N}=\mathrm{Not}$ Sure; A=Agree; $\mathrm{SA}=$ Strongly Agree

Note: $n=20$

\subsection{Perceptions on Learning Culture in Organization}

Respondents were asked to indicate their perceptions regarding learning culture in their organization using a Likert scale of 1-Strongly Disagree, 2-Disagree, 3-Not Sure, 4-Agree and 5Strongly Agree. The result as portrayed in Table 5 reveals that $55 \%$ of the respondents agreed that their top management supported the vision of a learning organization, $30 \%$ strongly agreed while the remaining $15 \%$ were not sure. Almost half $(45 \%)$ of the respondents agreed that their organization had rewarded staff who took the initiative to learn. On the other hand, $40 \%$ of the respondents did not agree while only $15 \%$ choose strongly agree. Majority $(65 \%)$ of the respondents agreed that their organization had motivated or encouraged staff in learning while $25 \%$ of the respondents strongly agreed. Only a small proportion (10\%) of the respondents were not sure. Half $(50 \%)$ of the respondents strongly agreed and another $45 \%$ agreed that their organization shared knowledge with each other, respectively. The remaining $5 \%$ of the respondents were not sure.
Table 5: Learning Culture in Organization

\begin{tabular}{|c|c|c|c|c|c|}
\hline Statements & SD & D & $\mathbf{N}$ & A & SA \\
\hline $\begin{array}{l}\text { 1. Top } \\
\text { management } \\
\text { supports the } \\
\text { vision of a } \\
\text { learning } \\
\text { organization }\end{array}$ & 0 & 0 & $\begin{array}{c}3 \\
(15 \%)\end{array}$ & $\begin{array}{c}11 \\
(55 \%)\end{array}$ & $\begin{array}{c}6 \\
(30 \%)\end{array}$ \\
\hline $\begin{array}{l}\text { 2. My } \\
\text { organization } \\
\text { rewards staff } \\
\text { for taking } \\
\text { initiative in } \\
\text { learning } \\
\end{array}$ & 0 & 0 & $\begin{array}{c}8 \\
(40 \%)\end{array}$ & $\begin{array}{c}9 \\
(45 \%)\end{array}$ & $\begin{array}{c}3 \\
(15 \%)\end{array}$ \\
\hline $\begin{array}{l}\text { 3. My } \\
\text { organization } \\
\text { motivates or } \\
\text { encourages } \\
\text { staffs in } \\
\text { learning }\end{array}$ & 0 & 0 & $\begin{array}{c}2 \\
(10 \%)\end{array}$ & $\begin{array}{c}13 \\
(65 \%)\end{array}$ & $\begin{array}{c}5 \\
(25 \%)\end{array}$ \\
\hline $\begin{array}{l}\text { 4. My } \\
\text { organization } \\
\text { encourages } \\
\text { sharing of } \\
\text { knowledge } \\
\text { with each } \\
\text { other's } \\
\end{array}$ & 0 & 0 & $\begin{array}{c}1 \\
(5 \%)\end{array}$ & $\begin{array}{c}9 \\
(45 \%)\end{array}$ & $\begin{array}{c}10 \\
(50 \%)\end{array}$ \\
\hline
\end{tabular}

Note: $\mathrm{SA}=$ Strongly Disagree; $\mathrm{D}=$ Disagree; $\mathrm{N}=\mathrm{Not}$ Sure; $\mathrm{A}=$ Agree; $\mathrm{SA}=$ Strongly Agree

Note: $n=20$

\subsection{Perceptions on Technology in Organization}

Respondents were asked to indicate their perceptions regarding learning culture in their organization using a Likert scale of 1-Strongly Disagree, 2-Disagree, 3Not Sure, 4-Agree and 5-Strongly Agree. Statements based on technology used in learning activities were measured using 4 statements and the result is presented in Table 6. It can be seen that more than half $(55 \%)$ of the respondents agreed that staff made frequent use of tools, methods and approaches for learning and collaborating with others, while $25 \%$ responded were not sure. On the other hand, $20 \%$ of the respondents strongly agreed with the statement. Majority of the respondents felt strongly agreed and agreed that an effective tool helps them in learning activities with $55 \%$ and $40 \%$ respectively. However, the remaining 5\% were not sure about that statement. Moreover, half $(50 \%)$ of the respondents agreed that technology helped them to improve communication between staff in all levels. On the other hand, $40 \%$ were not sure while a small proportion $(10 \%)$ of the respondents strongly agreed about it. Lastly, respondents were asked whether technology was successfully used to enable staff to identify internal sources of expertise. The result showed that both $40 \%$ strongly agreed and agreed respectively with $20 \%$ of the respondents who were not sure. 
Table 6: Technology in Learning Activities

\begin{tabular}{|c|c|c|c|c|c|}
\hline Statements & SD & D & $\mathbf{N}$ & $\mathbf{A}$ & SA \\
\hline $\begin{array}{l}\text { 1. Staff make } \\
\text { frequent use } \\
\text { of tools, } \\
\text { methods, and } \\
\text { approaches } \\
\text { for leaning } \\
\text { and } \\
\text { collaborating } \\
\text { with others. }\end{array}$ & 0 & 0 & $\begin{array}{c}5 \\
(25 \%)\end{array}$ & $\begin{array}{c}11 \\
(55 \%)\end{array}$ & $\begin{array}{c}4 \\
(20 \%)\end{array}$ \\
\hline $\begin{array}{l}\text { 2. Effective } \\
\text { technology } \\
\text { helps me in } \\
\text { learning } \\
\text { activities }\end{array}$ & 0 & 0 & $\begin{array}{c}1 \\
(5 \%)\end{array}$ & $\begin{array}{c}8 \\
(40 \%)\end{array}$ & $\begin{array}{c}11 \\
(55 \%)\end{array}$ \\
\hline $\begin{array}{l}\text { 3. Technology } \\
\text { helps me to } \\
\text { improve } \\
\text { communicatio } \\
\mathrm{n} \text { between } \\
\text { staff in all } \\
\text { levels }\end{array}$ & 0 & 0 & $\begin{array}{c}8 \\
(40 \%)\end{array}$ & $\begin{array}{c}10 \\
(50 \%)\end{array}$ & $\begin{array}{c}2 \\
(10 \%)\end{array}$ \\
\hline $\begin{array}{l}\text { 4. Technology is } \\
\text { successfully } \\
\text { used to enable } \\
\text { staff to } \\
\text { identify } \\
\text { internal } \\
\text { sources of } \\
\text { expertise }\end{array}$ & 0 & 0 & $\begin{array}{c}4 \\
(20 \%)\end{array}$ & $\begin{array}{c}8 \\
(40 \%)\end{array}$ & $\begin{array}{c}8 \\
(40 \%)\end{array}$ \\
\hline
\end{tabular}

\section{Discussion and Conclusion}

This study found that majority of the respondents were aware that the organization had the attributes of a learning organization and all felt that learning activities were important in their organization. They also agreed that people are practicing the three components of learning organization (employee empowerment, learning culture, and technology in learning activities) in the organization. The organization has provided learning facilities to support learning activities in the organization. Meeting room can be utilized as a place for employee to conduct training and brainstorming. The activities involve face-to-face interaction among employees and trainers thus can generate ideas and solve the issues faced by the departments and specifically the organization. The way of learning has been shifted with the advancement of technology in the 21 st century. KM portal is a platform that provides a uniform interface of learning. Employees no longer need to sit in a room to learn but they can aid sharing and collaborate with colleagues virtually. On learning culture, majority of the respondents agreed that their organization had motivated or encouraged staff in learning. Regarding employee empowerment, almost half of the respondents agreed that their leader had encouraged delegation of works to lower staff and expected leadership practices to staff at all levels. Concerning the technology in learning activities, majority of the respondents felt strongly agreed that an effective tool had helped them in learning activities. Overall, the result had shown positive perceptions with regard to learning culture, people empowerment and use of technology in learning activities among staff in the organization. This pilot study was based on data from only one research-based organization, hence the results should not be generalized to other organizations. In the future, studies should use a larger representative sample with respondents randomly selected from the targeted population of organizations. The items in the instrument should also include more dimensions on the practices of learning organizations namely, leadership, communication, policies and processes, and people. The results are useful to organizations that aspire to become a learning organization whereby people are learning continuously to create, acquire, share, and apply the knowledge and thus, competitive advantage and organizational performance are maximized.

\section{References}

[1] P. M. Senge, The Fifth Discipline: The Art and Practice of the Learning Organization. New York: Currency Doubleday, 1990.

[2] M. Pedler, J. Burgoyne, and T. Boydell, The Learning Company. London: McGraw-Hill, 1991.

[3] M. J. Marquardt, Building the Learning Organization: A System Approach to Quantum Improvement and Global Success. New York, McGraw-Hill, 1996.

[4] S. Ratner, Emerging Issues in Learning Communities. St. Albans, Vermont: Yellow Wood Associates, 1997.

[5] J. Redding. "Hardwiring the Learning Organization" Training \& Development, pp. 61-67, 1997.

[6] N. A. Kassim, Learning Organization in Malaysian University Libraries an Exploration. Shah Alam, Malaysia: UiTM Press, 2010.

[7] D. Meggison and M. Pedler, Self-development: A Facilitator's Guide. London: McGraw-Hill, 1992.

[8] D. A. Gavin, "Building a Learning Organization", Harvard Business Review, 1993 https://hbr.org/1993/07/building-a-learning-organization

[9] K. A. S. Abdullah and N. A. Kassim, Organizational Learning in Learning Organization. Shah Alam, Malaysia: UiTM Press, 2010. 
[10] K. E. Watkins and V. J. Marsick, Sculpting the Learning Organization. San Francisco: Jossey-Bass, 1993.

[11] K. E. Watkins and V. J. Marsick, In Action: Creating the Learning Organization. Alexandria, VA: American Society for Training and Development, 1996.

[12] J. Farago and D. J. Skyrme, "Learning Organization", Insight, vol.3, 1995.

http://www.skyrme.com/insights/31rnorg.htm

[13] O. Serrat, Building a Learning Organization. Washington, DC: Asian Development Bank, 2010.

[14] Cambridge University Press, "Empowerment", 2019, https://dictionary.cambridge.org/dictionary/english/empow erment

[15] A. Yuesti and K. Sumantra, "Empowerment on the Knowledge and Learning Organization for Community Development”, Scientific Research Journal, vol.5, pp.96$101,2017$.

[16] R. V. Ford, "Organizational Learning, Change and Power: Toward a Practice-theory Framework", The Learning Organization, vol.13, pp. 495-524, 2006.

[17] B. Mishra and A. U. Bhaskar, "Empowerment: A Necessary Attributes of a Learning Organization?", Organization and Markets in Emerging Economies, vol.1, pp.48-70, 2006.

[18] W. D. Hitt, "The Learning Organization: Some Reflections on Organizational Renewal", Leadership \& Organization Development Journal, vol.16, pp.17-25, 1995.

[19] D. Ulrich, "Profiling Organizational Competitiveness: Cultivating Capabilities", Human Resource Planning, vol.16, pp.1-17, 1993.

[20] E. A. Locke and V. K. Jain, "Organizational Learning and Continuous Improvement", The International Journal of Organizational, vol.3, pp.45-68, 1995.

[21] E. Roberts, "Team Training: When is Enough ... Enough?", The Journal of Quality \& Participation, vol.20, pp.16-20, 1997.

[22] N. A. Kassim, Learning Organization: Multiple Papers as Research Outcome. Shah Alam: Malaysia, UiTM Press, 2010.

[23] J. Hong, "Structuring for Organizational Learning", The Learning Organization, vol.6, pp.173-186, 1999.

[24] P. Chinowsky, K. Molenaar, and A. Realph, "Learning Organization in Construction", Journal of Management in Engineering, vol.3, pp.27-34, 2007.

[25] C. Lee, "Building a Continuous Learning Culture Key Benefits for Businesses", 2018, https://www.simplilearn.com/benefits-continuous-learningculture-article
[26] N. A. Kassim, K. Baharuddin, and M. R. Baba, "Team Member Effectiveness and Employee Performance in a Telecommunication Organization", International Journal for Infonomics, vol.11, pp.1824-1833, 2018.

[27] C. Zehir, E. Yilmaz, and H. Velioglu, "The Impact of Information Technology Practices and Organizational Learning on Firm Innovation and Performance", Global Journal of Global Strategic Management, vol.4, pp.24-37, 2008.

[28] N. A. Kassim, M. F. Baharuddin, and Z. A. Samad, "Knowledge Management Practices and Organizational Performance in Malaysia Government Institution", International Journal for Infonomics, vol.9, pp.1233-1238, 2016.

\section{Acknowledgements}

The authors wish to thank all respondents who had participated in the survey. 